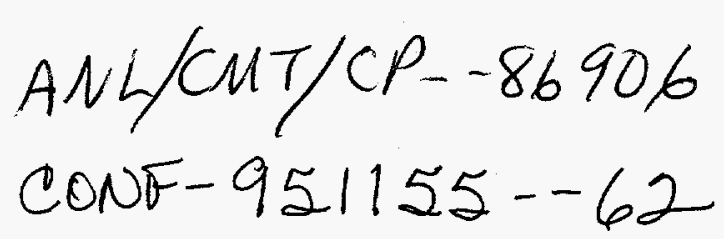

\title{
APATITE- AND MONAZITE-BEARING GLASS-CRYSTAL COMPOSITES FOR THE IMMOBILIZATION OF LOW-LEVEL NUCLEAR AND HAZARDOUS WASTES
}

D. J. Wronkiewicz, S. F. Wolf, and T. S. DiSanto

RE?

FEB 10 wis

\author{
ARGONNE NATIONAL LABORATORY \\ Chemical Technology Division \\ 9700 South Cass Avenue \\ Argonne, IL 60439-4837
}

The submited manuscript has been
authored by a contractor of the U.S.
Govemment under contract No. W-31-108-
ENG-38. Accordingly, the U.S. Govemment
retains a nonexclusive, royalty-free license
to publish or reproduce the published form of
this contribution, or allow others to do so, for
U.S. Govemment purposes.

OSTI

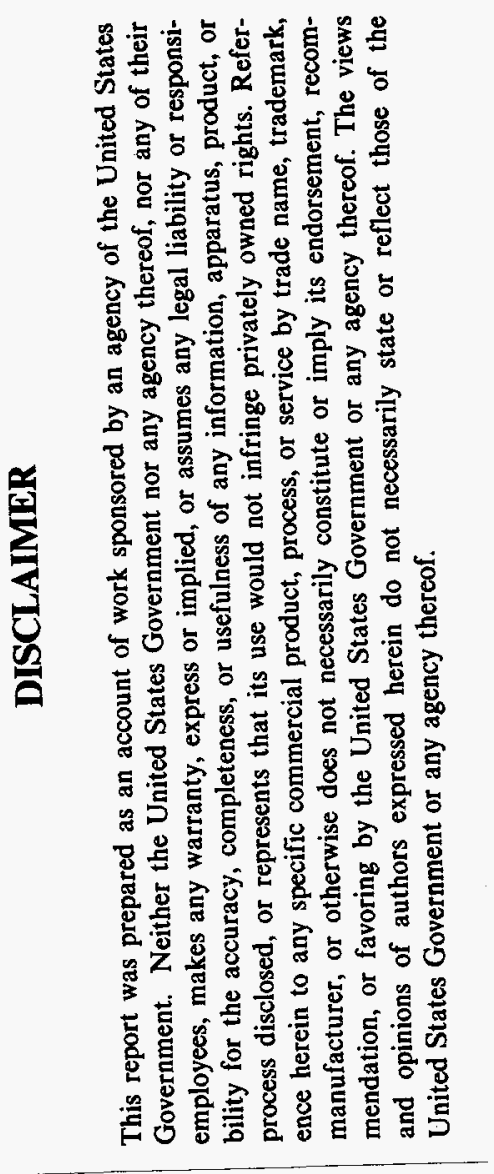

\author{
Submitted to \\ Materials Research Society Meeting \\ Boston, MA \\ November 27-December 1, 1995
}

This work supported by the U.S. Department of Energy, Office of Technology Development, under contract W-31-109-ENG-38. 


\section{DISCLAMMER}

Portions of this document may be illegible in electronic image products. Images are produced from the best available original document. 


\section{APATITE- AND MONAZITE-BEARING GLASS-CRYSTAL COMPOSITES FOR THE IMMOBILIZATION OF LOW-LEVEL NLCLEAR AND HAZARDOUS WASTES}

D.J. Wronkiewicz, S.F. Wolf, and T.S. DiSanto, Argonne National Laboratory, CMT, 9700

South Cass Ave., Argonne, IL 60439, wronkiewicz@cmt.anl.gov.

\section{ABSTRACT}

This study demonstrates that glass-crystal composite waste forms can be produced from waste streams containing high proportions of phosphorus, transition metals, and/or halides. The crystalline phases produced in crucible-scale melts include apatite, monazite, spinels, and a $\mathrm{Zr}-\mathrm{Si}-\mathrm{Fe}-\mathrm{Ti}$ phase. These phases readily incorporated radionuclide and toxic metals into their crystal structures, while corrosion tests have demonstrated that glass-crystal composites can be up to 300-fold more durable than simulated high-level nuclear waste glasses, such as SRL $202 \mathrm{U}$.

\section{INTRODUCTION}

The safe disposal of radioactive and toxic wastes requires the development of treatment procedures that effectively result in the isolation of these hazardous components from the biosphere for an extended period of time. Glass-crystal composite (GCC) waste forms are being evaluated at Argonne National Laboratory for their potential use in the disposal of low-level nuclear and hazardous waste materials. The use of GCCs as a waste form combines the advantageous features of both the excellent durability exhibited by predominantly crystalline waste forms, such as Synroc, with the processing advantages of using commercially available vitrification technologies. This waste form is being developed within the framework of the DOE's Minimum Additive Waste Stabilization (MAWS) program. The MAWS protocol involves the blending of multiple waste streams to achieve an optimal feed composition, thus eliminating the need to use large amounts of additives to produce an acceptable waste form. Previous studies [1,2] have shown that the GCCs can be applied to the treatment of waste streams with actinides and high-metal contents. For example, contaminants such as $\mathrm{U}$ and $\mathrm{Ce}$ ( $\mathrm{Ce}$ as an analogue for plutonium) were incorporated into zirconolite [ $\mathrm{CaZrTi}_{2} \mathrm{O}_{7}$ ], while $\mathrm{Cr}, \mathrm{Ni}$, and $\mathrm{Cd}$ were incorporated into spinels

$\left[(\mathrm{Fe}, \mathrm{Ni}, \mathrm{Mg}, \mathrm{Zn}, \mathrm{Mn})(\mathrm{Al}, \mathrm{Fe}, \mathrm{Ti}, \mathrm{Cr})_{2} \mathrm{O}_{4}\right]$. In addition, industrial-scale $\mathrm{GCC}$ processing has been demonstrated with a $900 \mathrm{~kg} / \mathrm{h}$ arc-melter operated by the U.S. Bureau of Mines in Albany, Oregon [3].

The current study demonstrates that apatite $\left[\mathrm{Ca}_{5}\left(\mathrm{PO}_{4}\right)_{3}(\mathrm{OH}, \mathrm{F}, \mathrm{Cl})\right]$ is also a promising medium for the disposal of radioactive and mixed wastes. Favorable characteristics include a high degree of resistance to chemical corrosion in neutral-to-alkaline environments, the ability to be formulated from elements already present in many DOE waste streams (e.g., $\mathrm{Ca}, \mathrm{P}, \mathrm{F}, \mathrm{Cl}$, and $\mathrm{S}$ ), accepted substitutions from a large array of radioactive and hazardous elements $\left({ }^{90} \mathrm{Sr},{ }^{137} \mathrm{Cs}\right.$, As, $\mathrm{Pb}, \mathrm{Ba}, \mathrm{Hg}, \mathrm{Cd}, \mathrm{Cr}, \mathrm{U}$, and $\mathrm{Ce}$ ), and the ability to be synthesized in waste processes ranging from vitrification to low-temperature solution precipitation. Also investigated as a potential crystalline waste host were monazite $\left[(\mathrm{Ce}, \mathrm{U}) \mathrm{PO}_{4}\right]$, because of its ability to incorporate large amounts of radionuclides, and spinels, because of their high degree of corrosion resistance and ability to incorporate toxic metals $[1,2]$.

In tests with simulated nuclear waste glasses, calcium and phosphorus that was liberated during corrosion testing was reprecipitated as hydroxyapatite on the surface of the altered samples $[4,5]$. This occurrence indicates that apatite is inherently more stable than the waste glasses from which its constituents were derived. One of the more convincing demonstrations of the stability of apatite can be found in a study conducted on samples from the Oklo natural reactor site in the Republic of Gabon, Africa. The apatites at this location were enriched in ${ }^{135} \mathrm{Ba}$ and ${ }^{137} \mathrm{Ba}$ (derived from the decay of ${ }^{135} \mathrm{Cs}$ and ${ }^{137} \mathrm{Cs}$, respectively) relative to the stable ${ }^{136} \mathrm{Ba}$ isotope, suggesting that the apatites may have retained these fissiogenic elements over a period of $\sim 1.7$ billion years [6]. 


\section{EXPERIMENTAL}

\section{Sample Casting}

Five sample melts were used as a basis for this investigation. The first three samples (G26, G27, and G29) were used to develop a preliminary compositional envelope for GCC processing. These samples were produced by combining various chemical additives (mostly as oxides) with uncontaminated Idaho National Engineering Laboratory soil that was ashed at $1100^{\circ} \mathrm{C}$ (Table I). The remaining two melts (G32 and G33) simulated waste stream compositions from the DOE sites at Fernald, Ohio and Oak Ridge National Laboratory (ORNL). These samples were produced entirely from chemical additive components. The Fernald sample simulated a mix of $36.4 \mathrm{wt} \%$ Pit 5 Sludge, $30.3 \mathrm{wt} \%$ scrap steel, $27.3 \mathrm{wt} \%$ FE7 soil, and $6.0 \mathrm{wt} \%$ additives (P and Ti). The ORNL sample simulated a mix of $46.4 \mathrm{wt} \% \mathrm{~K} 1407$ Pond Waste, $39.7 \mathrm{wt} \%$ ORNL soil, $6.6 \mathrm{wt} \%$ West End Treatment Facility sludge, $6.6 \mathrm{wt} \%$ Toxic Substances Control Act ash, and only $0.7 \mathrm{wt} \%$ additives (fluorine). Simulated amounts of EPA listed toxic and carcinogenic metals $\left(\mathrm{Pb}, \mathrm{Cr}, \mathrm{Ni}, \mathrm{Ba}\right.$, and $\mathrm{As}$ ), $\mathrm{U}, \mathrm{Sr}$, and $\mathrm{Ce}$ (the latter two as surrogates for ${ }^{90} \mathrm{Sr}$ and $\mathrm{Pu}$, respectively) were also added to the samples in their oxide forms.

The sample powders were thoroughly blended and then added to a platinum crucible.

Samples were formed by melting at $1400^{\circ} \mathrm{C}$ for 40 minutes, cooling to $1150^{\circ} \mathrm{C}$, holding at this temperature for three hours, and then cooling the samples inside the test furnace down to room temperature. All samples were subsequently annealed at $500^{\circ} \mathrm{C}$ for one hour to remove thermal stresses that built up during solidification. Mass losses for the five samples averaged $\sim 3 \%$, however, investigations have not been conducted to determine what elements were volatilized. Crystal formation was induced by the addition of chemical additives $(\mathrm{Zr}, \mathrm{Ti}, \mathrm{F}$, and $\mathrm{P}$ ), proper blending of the simulated waste streams, and slow cooling of the molten material. Desired crystalline phases were targeted based on their ability to incorporate radioactive and toxic components and to resist aqueous corrosion.

\section{Test Procedures}

The GCCs were subjected to the static Product Consistency Test (PCT) and Vapor Hydration Test (VHT) so that their durabilities could be compared against other waste forms tested by similar methods. Toxicity Characteristic Leaching Procedure (TCLP) Tests were also performed to determine the applicability of the GCCs for EPA licensing as a nonhazardous waste.

The PCTs were conducted in sealed Teflon vessels using a sample size fraction of -100 to +200 mesh (75 to $150 \mathrm{~mm}$ ), deionized water, a sample surface area/liquid volume (S/V) ratio of $\sim 2000 \mathrm{~m}^{-1}$, a temperature of $90^{\circ} \mathrm{C}$, and test intervals of 7,28, and 91 days. After completion of the

Table I. Normalized feed composition of glass-crystal composites (element wt\%)

\begin{tabular}{|c|c|c|c|c|c|c|c|c|c|c|c|}
\hline Element & G26 & G27 & G29 & G32 & G33 & Element & G26 & G27 & G29 & G32 & G33 \\
\hline $\mathrm{Si}$ & 34.43 & 53.49 & 25.57 & 19.12 & 32.15 & $\mathrm{Cr}$ & 0.76 & 0.83 & 0.01 & 0.55 & 0.20 \\
\hline $\mathrm{Al}$ & 5.95 & 8.16 & 5.61 & 3.64 & 13.28 & $\mathrm{~Pb}$ & 0.00 & 0.00 & 4.09 & 0.00 & 0.06 \\
\hline $\mathrm{Fe}$ & 14.11 & 12.75 & 14.57 & 31.36 & 14.26 & As & 0.01 & 0.01 & 2.26 & 0.00 & 0.02 \\
\hline $\mathrm{Ca}$ & 15.36 & 7.28 & 15.51 & 19.02 & 21.80 & $\mathrm{Ba}$ & 0.08 & 0.10 & 0.07 & 1.06 & 0.01 \\
\hline P & 5.34 & 2.28 & 6.44 & 3.26 & 6.64 & $\mathrm{U}$ & 3.07 & 3.59 & 4.27 & 1.14 & 0.56 \\
\hline $\mathrm{K}$ & 1.99 & 2.71 & 1.87 & 0.93 & 3.29 & $\mathrm{Ce}$ & 2.81 & 3.31 & 3.94 & 0.00 & 0.00 \\
\hline $\mathrm{Mg}$ & 1.29 & 1.77 & 1.22 & 8.57 & 2.27 & $\mathrm{Ni}$ & 0.53 & 0.56 & 0.01 & 0.79 & 1.79 \\
\hline $\mathrm{Na}$ & 0.79 & 1.86 & 0.75 & 0.84 & 1.22 & $\mathrm{Zn}$ & 0.01 & 0.01 & 0.01 & 0.00 & 0.09 \\
\hline $\mathrm{Ti}$ & 5.51 & 1.14 & 3.43 & 3.33 & 1.10 & $\mathrm{Cu}$ & 0.01 & 0.01 & 0.01 & 0.00 & 0.25 \\
\hline $\mathrm{Zr}$ & 5.20 & 0.02 & 3.27 & 0.01 & 0.00 & $\mathbf{F}$ & 2.66 & 0.00 & 2.63 & 5.57 & 0.14 \\
\hline $\mathrm{Mn}$ & 0.06 & 0.08 & 0.06 & 0.15 & 0.49 & $\mathrm{Cl}$ & 0.00 & 0.00 & 0.00 & 0.00 & 0.06 \\
\hline $\mathrm{Sr}$ & 0.03 & 0.04 & 4.40 & 0.03 & 0.00 & $S$ & 0.00 & 0.00 & 0.00 & 0.63 & 0.31 \\
\hline
\end{tabular}


prescribed PCT intervals, sample aliquots were withdrawn, at test temperature, for solution analyses. Cation determinations were made with an inductively coupled plasma/mass spectrometer (ICP/MS) and $\mathrm{pH}$ determinations with a combination electrode. All analytical measurements, including $\mathrm{pH}$, were made at room temperature. Cation accuracy and precision were both better than $10 \%$, while precision for the $\mathrm{pH}$ analyses was $\sim 0.02 \mathrm{pH}$ units. Reacted surfaces of PCT solids were also analyzed with scanning electron microscopy/energy dispersive X-ray spectroscopy (SEM/EDS).

Disk-shaped monoliths ( 1 -mm thick, $10-\mathrm{mm}$ diameter) were reacted in a VHT at $200^{\circ} \mathrm{C}$ for periods of 7,28 , or 91 days. Details of the VHT procedure were previously described elsewhere [5]. Sample monoliths were characterized with respect to both the fate of the primary crystalline and glassy components of the waste form and the formation of alteration phases. The high test temperature and $\mathrm{S} / \mathrm{V}$ ratio $\left(\sim 10^{6} \mathrm{~m}^{-1}\right)$ used in these tests accelerated the reactions occurring at the sample surface, thereby inducing the formation of a long-term corrosion sequence of minerals within a relatively short time interval. Previous studies have shown that 50,000 to 140,000 year alteration trends produced during volcanic glass alteration in near-surface $\left(-25^{\circ} \mathrm{C}\right)$ lacustrine environments can be correlated with those occurring in VHTs at $200^{\circ} \mathrm{C}$ in as little as 21 days [7]. This finding suggests that the reaction mechanism controlling the corrosion of glass may remain unchanged within the temperature range of $25-200^{\circ} \mathrm{C}$.

TCLP tests were conducted following established EPA testing procedures. This test was used to measured the leachability of eight toxic elements ( $\mathrm{Ag}, \mathrm{As}, \mathrm{Ba}, \mathrm{Cd}, \mathrm{Cr}, \mathrm{Hg}, \mathrm{Pb}$, and $\mathrm{Se}$ ) after reaction of the samples in an agitated sodium acetate buffered solution for 18 hours at ambient room temperature. The results were used to determine if a sample can meet the EPA regulatory release requirements for hazardous wastes, which are set at a concentration 100 times greater than the established drinking water limit for each of the contaminants. The leaching characteristics of nickel were also examined, using the land-based disposal limit $(0.32 \mathrm{ppm})$ as the targeted maximum leachate level for this element.

\section{RESULTS AND DISCUSSION}

\section{Waste Form Composition and Crystallography}

Apatite $\left[\mathrm{Ca}_{5}\left(\mathrm{PO}_{4}\right)_{3}(\mathrm{~F}, \mathrm{Cl}, \mathrm{OH})\right]$ readily formed in melts in which $\mathrm{Ca}, \mathrm{P}$, and $\mathrm{F}$ were present. This phase appeared as elongate crystals suspended in a predominantly glassy matrix, and was also able to incorporate a wide array of toxic, radioactive, and radioactive surrogate elements in its crystal structure (Table II). Apatite possesses the general overall compositional structure of $\mathrm{A}_{5}\left(\mathrm{BO}_{4}\right)_{3} \mathrm{X}$. Various literature sources plus the present study indicate that the following substitutions are possible (bold letters indicate substitutions identified in this study):

$$
\begin{aligned}
& \mathrm{A}=\mathrm{Ca}, \mathrm{Sr}, \mathrm{Ce}, \mathrm{Pb}, \mathrm{Ba}, \mathrm{Hg}, \mathrm{Cd}, \mathrm{Tl}, \mathrm{Na}, \mathrm{K}, \mathrm{Mg}, \mathrm{Rb}, \mathrm{Cs}, \mathrm{Y}, \mathrm{Zn}, \mathrm{Bi}, \mathrm{Mn} \\
& \mathrm{B}=\mathrm{P}, \mathrm{As}, \mathrm{U}, \mathrm{Cr}, \mathrm{S}, \mathrm{Si}, \mathrm{V}, \mathrm{B}, \mathrm{Ge}, \mathrm{C} \\
& \mathrm{X}=\mathrm{F}, \mathrm{Cl}, \mathrm{OH}
\end{aligned}
$$

Replacement within the apatite structure often employs a charge-balanced coupled substitution. For example, the substitution of $\mathrm{S}^{6+}$ for $\mathrm{P}^{5+}$ may be compensated for by either the substitution of $\mathrm{Na}^{+}$for $\mathrm{Ca}^{2+}$, or $\mathrm{Si}^{4+}$ for $\mathrm{P}^{5+}$. Such substitutions include elements with valences ranging from $1+$ to $6+$, and ionic radii ranging from 0.015 to $0.169 \mathrm{~nm}$. The above substitutions suggest that apatite may also be used in the disposal of waste streams containing the radioactive elements ${ }^{14} \mathrm{C}$, ${ }^{90} \mathrm{Sr},{ }^{137} \mathrm{Cs},{ }^{129} \mathrm{I},{ }^{99} \mathrm{Tc}, \mathrm{U}, \mathrm{Th}, \mathrm{Ra}$, and $\mathrm{Pu}$ (by analogy with the incorporation of $\mathrm{Ce}$ ) and the toxic elements $\mathrm{Ag}, \mathrm{Cu}, \mathrm{Se}$, and $\mathrm{Ni}$.

Many of the elements incorporated in apatite have limited solubilities in waste glasses, thus, processing of these elements by traditional vitrification techniques would probably require their dilution by large volumes of glass-forming components. The flexible range allowed in the feed compositions for the GCCs melts would allow the apatite-bearing melts to be produced from many DOE waste streams with a minimal amount of processing additives. This supposition was 
Table II. Composition of crystalline phases as determined with SEM/EDS (element wt $\%$ )

\begin{tabular}{|c|c|c|c|c|c|}
\hline & $\begin{array}{c}\text { Apatite } \\
\text { G26 }\end{array}$ & $\begin{array}{c}\text { Apatite } \\
\text { G29 } \\
\end{array}$ & $\begin{array}{c}\text { Monazite } \\
\text { G27 } \\
\end{array}$ & $\begin{array}{c}\text { Spinel } \\
\text { G26 }\end{array}$ & $\begin{array}{c}\text { Spinel } \\
\text { G27 }\end{array}$ \\
\hline $\mathrm{Ca}$ & 35.2 & .31 .1 & 0.9 & 0.3 & 0.3 \\
\hline $\mathrm{P}$ & 16.3 & 12.8 & 12.8 & & 0.3 \\
\hline $\mathrm{F}$ & 3.8 & 3.4 & & & \\
\hline $\mathrm{Fe}$ & 0.5 & 0.9 & & 34.9 & 52.7 \\
\hline $\mathrm{Al}$ & 0.1 & 0.3 & 0.1 & 0.5 & 1.7 \\
\hline $\mathrm{Mg}$ & 0.3 & & & 0.8 & 1.0 \\
\hline $\mathrm{Si}$ & 1.8 & 1.6 & 0.2 & & \\
\hline $\mathrm{Na}$ & 0.4 & & & & \\
\hline K & 0.1 & 0.2 & & & \\
\hline $\mathrm{O}$ & 38.3 & 34.4 & 27.2 & 31.7 & 30.1 \\
\hline $\mathrm{Ti}$ & & 0.2 & & 6.4 & \\
\hline $\mathrm{Zr}$ & & 1.1 & & & \\
\hline $\mathrm{U}$ & 0.1 & 0.5 & 2.4 & & 0.2 \\
\hline $\mathrm{Ce}$ & 3.1 & 3.3 & 56.4 & & 0.9 \\
\hline As & & 2.5 & & & \\
\hline $\mathrm{Sr}$ & & 4.7 & & & \\
\hline $\mathrm{Pb}$ & & 3.1 & & & \\
\hline $\mathrm{Cr}$ & & & & 23.4 & \\
\hline $\mathrm{Ni}$ & & & & 2.1 & 9.3 \\
\hline
\end{tabular}

evaluated by producing two apatite-bearing melts using feed compositions that simulate those of wastes from Fernald, Ohio (G32) and ORNL (G33). Both samples readily produced apatitebearing melts while requiring only 6.1 and $0.7 \mathrm{wt} \%$ additives, respectively.

The inclusion of fluorine in apatite phase could also increase the durability of any associated glass matrix material since halogens (and hydroxide) may destabilize the network structure of glasses. The incorporation of fluorine and chlorine in crystal phases may also reduce the level of corrosive volatiles evolved to the off-gas system during melting, thereby reducing the corrosion of melter components.

Spinel crystals were produced in melts that had high iron. The formation of spinels is desirable in melts that have large proportions of scrap metals, because the solubility of iron is relatively limited in glass waste forms. Spinels also can incorporate the toxic metals $\mathrm{Cr}, \mathrm{Ni}$, and $\mathrm{Cd}$ in their structures, and are highly resistant to aqueous corrosion (Table II) $[1,2]$. The formation of spinels was the primary requirement for the high melting temperatures used in these tests, thus melt temperatures for apatite-bearing waste forms could be reduced when large amounts of metal components are not included in the waste stream.

The formation of monazite $\left[(\mathrm{Ce}, \mathrm{U}) \mathrm{PO}_{4}\right]$ was induced in a phosphorus-bearing sample that did not contain any $\mathrm{F}$ and $\mathrm{Cl}$ (G27, Table II). Relative to apatite, monazite appears to be more limited in the range of elements accepted in its crystal structure, however, the loadings of $U, C e$, and $\mathrm{Th}$ (the latter was not examined in the present investigation) are extremely high. This phase appeared as poorly formed, somewhat blocky grains.

Accessory phases formed from these melts include quartz $\left(\mathrm{SiO}_{2}\right)$, iron-silicates, zircon $\left(\mathrm{ZrSiO}_{4}\right)$, and an unidentified fine-grained $\mathrm{Zr}$-Si-Fe-Ti phase, with the latter two phases resulting from the addition of zirconium oxide. A SEM/EDS examination revealed that the zircons were devoid of uranium, while the $\mathrm{Zr}$-Si-Fe-Ti phase contained significant quantities of $\mathrm{U}(-20 \mathrm{wt} \%$ $\mathrm{UO}_{2}$ ), and minor amounts of $\mathrm{Ce}, \mathrm{As}$, and $\mathrm{Sr}$.

All glass matrix regions were dominated by the presence of $\mathrm{Si}$, with lesser amounts of $\mathrm{Al}$, $\mathrm{Ca}, \mathrm{Fe}$, and $\mathrm{K}$. Some samples also contained glass-immiscible regions that were enriched in $\mathrm{Si}$ relative to the primary glass matrix material. Traces of toxic metals, $\mathrm{U}$, and $\mathrm{Ce}$ were also detected in the primary glass matrix, while these elements were below SEM/EDS detection limits in the immiscible glass regions. 
Bulk partition coefficient ratios were calculated for hazardous constituents by using the SEM/EDS analyses of the crystalline and primary glass matrix regions of the samples (Table III). Results of these calculations indicate that $\mathrm{Ni}$ and $\mathrm{Cr}$ were strongly partitioned into the spinels; while $U$ and $C e$ were strongly partitioned into monazite. In sample $G 26$, apatite displayed a strong partition coefficient for $\mathrm{Ce}$ and a near-equal distribution of $\mathrm{U}$ between the crystalline apatite and glass material. In sample G29, there was a small preferential enrichment of $\mathrm{Ce}, \mathrm{As}$, and $\mathrm{Sr}$ in the apatite, whereas $\mathrm{Pb}$ and $\mathrm{U}$ were only weakly partitioned into this phase. The $\mathrm{Zr}-\mathrm{Si}$-Fe-Ti phase displayed a strong partition coefficient for $\mathrm{Ce}$ and $\mathrm{U}$ in sample $\mathrm{G} 26$, a strong coefficient for $\mathrm{Ce}$ in sample G29, and a moderate to weak coefficient for Ce, As, and Sr in sample G29.

\section{Durability Tests}

The GCC leachate $\mathrm{pH}$ values ranged from 8.2 to 9.4 for samples $\mathrm{G} 26, \mathrm{G} 29$, and $\mathrm{G} 32$, and 5.2 to 6.5 for samples G27 and G33, during PCT periods of 7 to 91 days (Fig. 1a). The 28- and 91-day normalized release levels of silicon can be correlated to the $\mathrm{pH}$ values, with the two low-pH samples showing the greatest silicon release (Fig. 1b). All samples, however, have silicon release levels that are slightly lower than those of simulated SRL 202U borosilicate waste glass [8], and significantly lower than the Environmental Assessment (EA) glass [9]. Release levels for uranium were approximately 100 - to 300-fold lower for the apatite- and monazite-bearing compositional envelope and simulated Fernald waste samples (G26, G27, G29, and G32), relative to SRL 202U glass (Fig. 1c). Uranium release from the simulated ORNL sample (G33) was somewhat higher, but was still $\sim 10$-fold lower than the SRL 202U glass. The post-test solid surfaces of the samples were also generally devoid of alteration phases, although more detailed investigations of these surfaces have yet to be conducted. It is of interest, though, that uranium levels tend to decrease in the longer term PCT tests relative to the shorter term tests, suggesting that there is some uptake of uranium by alteration phases or perhaps by sorption on primary apatite grains.

Results from the VHTs also suggest that the GCCs are a durable waste form. Overall appearances of the reacted sample surfaces after testing and the compositions of the alteration phases suggest that the primary crystalline phases are relatively inert to chemical attack. The SEM/EDS investigations revealed only minimum development of secondary reaction products on the samples, with the hazardous and radioactive elements that were partitioned into the crystalline phases during melt solidification being nearly completely absent from the altered sample surfaces. The alteration phases that were found were composed of elements derived from the corrosion of the glass matrix material. However, the abundance of these phases were also relatively limited, indicating a high-degree of chemical durability for the glass matrix material as well.

\begin{tabular}{llccc}
\multicolumn{5}{c}{ Table III. $\begin{array}{l}\text { Partition coefficients }\left(\mathrm{D}_{\mathrm{i}}=\mathrm{C}_{\mathrm{Crysta}} / \mathrm{C}_{\mathrm{Glass}}\right) \\
\text { glass-crystal composite samples }\end{array}$} \\
\hline Crystal Host & $\mathrm{Cr}$ & $\mathrm{G} 26$ & $\mathrm{G} 29$ & $\mathrm{G} 27$ \\
\hline Apatite & $\mathrm{D}_{\mathrm{U}}$ & 0.89 & 0.07 & \\
& $\mathrm{D}_{\mathrm{Ce}}$ & 67 & 1.2 & \\
& $\mathrm{D}_{\mathrm{Pb}}$ & & 0.31 & \\
& $\mathrm{D}_{\mathrm{As}}$ & & 1.4 & \\
& $\mathrm{D}_{\mathrm{Sr}}$ & & 1.2 & \\
Zr-Si-Fe-Ti Phase & $\mathrm{D}_{\mathrm{U}}$ & 13 & 5.2 & \\
& $\mathrm{D}_{\mathrm{Ce}}$ & 21 & 0.68 & \\
& $\mathrm{D}_{\mathrm{As}}$ & & 0.20 & \\
& $\mathrm{D}_{\mathrm{Sr}}$ & & 0.84 & \\
Monazite & $\mathrm{D}_{\mathrm{U}}$ & & & 8.4 \\
& $\mathrm{D}_{\mathrm{Ce}}$ & & & 29 \\
Spinel & $\mathrm{D}_{\mathrm{C}}$ & 117 & & 17 \\
& $\mathrm{D}_{\mathrm{Ni}}$ & 10.0 & & 33 \\
\hline
\end{tabular}



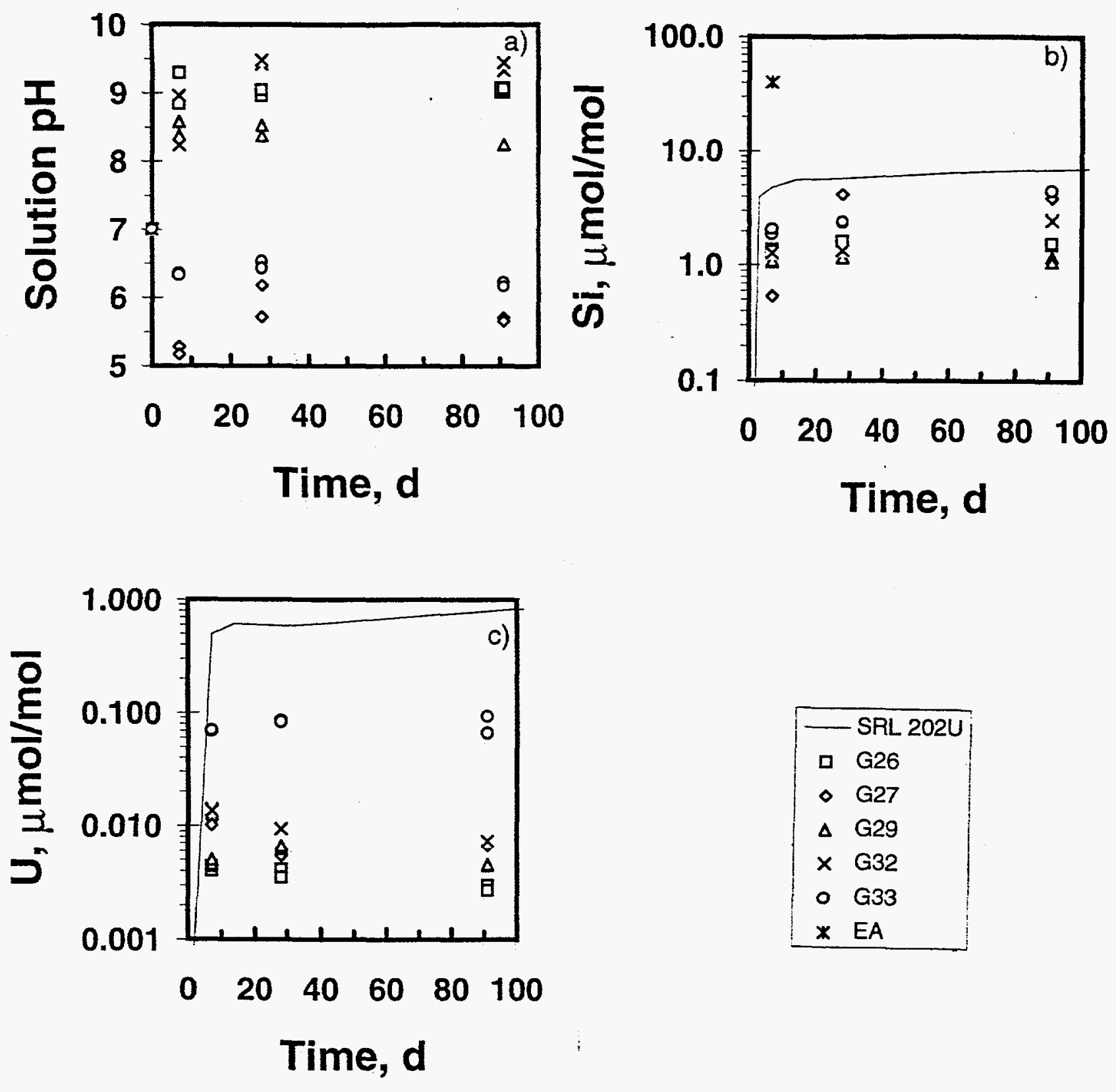

Figure 1. Product consistency test for glass-crystal composite and simulated high-level waste glass samples. All tests were conducted in deionized water, at $90^{\circ} \mathrm{C}$, at a solids surface area/liquid volume ratio of $-2000 \mathrm{~m}^{-1}$. Glass-crystal composite sample compositions are given in Table I, while the composition and solution release data for the SRL 202U and Environmental Assessment (EA) glass are from [8] and [9], respectively. The Si and U release data are given as normalized elemental release in $\mathrm{mmol}$ solution/mol solid.

(a) $\mathrm{pH}$, (b) silicon, and (c) uranium. 
Table IV. Results from Toxicity Characteristic Leaching Procedure tests (values in ppm)

\begin{tabular}{llllllllll}
\hline Sample & $\mathrm{Cr}$ & $\mathrm{Pb}$ & $\mathrm{Cd}$ & $\mathrm{Ba}$ & $\mathrm{As}$ & $\mathrm{Hg}$ & $\mathrm{Se}$ & $\mathrm{Ag}$ & $\mathrm{Ni}$ \\
\hline G26 & 0.012 & 0.009 & 0.004 & 0.153 & 0.001 & 0.001 & 0.002 & 0.000 & 0.018 \\
G27 & 0.014 & 0.07 & 0.016 & 0.298 & 0.001 & 0.001 & 0.002 & 0.000 & 0.042 \\
G29 & 0.013 & 0.127 & 0.006 & 0.167 & 0.178 & 0.001 & 0.001 & 0.000 & 0.007 \\
G32 & 0.014 & 0.003 & 0.001 & 0.923 & 0.001 & 0.001 & 0.003 & 0.000 & 0.021 \\
G33 & 0.014 & 0.027 & 0.003 & 0.171 & 0.004 & 0.001 & 0.006 & 0.000 & 0.126 \\
EPA Limit & 5 & 5 & 1 & 100 & 5 & 0.2 & 1 & 5 & 0.32 \\
\hline
\end{tabular}

Results from the TCLP tests indicate that the release levels for toxic elements were well below EPA established limits for hazardous waste declassification (Table IV), even for samples where waste loadings were relatively high. Particularly encouraging was the low release of lead from sample G29. Lead release from GCCs had been a concern due to the near complete exclusion of this element from crystalline phases $[1,2]$. In sample 629 , a limited portion of the lead was incorporated into the durable apatite phase, thereby contributing to the low amount of lead released to solution.

\section{CONCLUSIONS}

GCCs composed of apatite, monazite, spinels and/or Zr-Si-Fe-Ti crystals can be produced from waste streams containing high proportions of phosphorus, transition metals, and/or halides. Results from a variety of corrosion tests have shown the GCCs to be much more durable than simulated high-level nuclear waste glasses, such as SRL 202U. Apatite and spinel also display considerable compositional versatility, in being able to incorporate a wide variety of radioactive and hazardous elements. For example, $\mathrm{Cs}, \mathrm{Sr}, \mathrm{U}, \mathrm{C}, \mathrm{Ce}, \mathrm{As}, \mathrm{Pb}, \mathrm{Ba}, \mathrm{Hg}, \mathrm{Cd}$, and $\mathrm{Cr}$ have been shown to be processable into apatite by this and other studies. A number of other elements, including ${ }^{129} \mathrm{I},{ }^{99} \mathrm{Tc}, \mathrm{Th}, \mathrm{Ra}, \mathrm{Pu}$ (by analogy with the incorporation of $\mathrm{Ce}$ ), $\mathrm{Ag}, \mathrm{Cu}$, and $\mathrm{Ni}$ may be incorporated in apatite as well.

The GCCs allow more processing versatility than a homogeneous glass material would allow, especially with respect to variable waste feed compositions. This versatility would be particularly important where the waste feed composition is poorly known and/or relatively heterogeneous (both scenarios are likely for low-level radioactive and mixed waste processing), and would also probably reduce the need for thorough homogenization of the waste stream materials prior to actual vitrification. The apatites could also be produced from elements already present in many DOE waste streams, thereby reducing overall disposal costs through a reduction in the need for purchased additives, and more importantly, a reduction in waste form volume.

Apatite also displays considerable flexibility in being able to be processed by several methods. Such versatility allows apatites to be produced in a fashion where the final apatitecontaining waste form can be targeted for specific DOE needs. For example, apatites may be produced in both high-temperature vitrification processing, as explored in this study, and lowtemperature precipitation processes $[10,11]$. The low-temperature techniques offer advantages in allowing for the processing of wastes without significant volatility of hazardous waste stream constituents and also represent a considerable reduction in energy processing costs relative to vitrification. Thus, the demonstrated flexibility in processing and composition, combined with its superior corrosion resistant properties, will allow apatite-bearing GCC processing to be applied to a variety of different DOE waste materials.

The stability of apatite in neutral- to high-pH environments suggests that this phase may serve as a suitable waste form in environments such as those that are present in arid-alkaline soils or in soils that have developed over a limestone bedrock. Apatite-bearing waste forms may also be used in more acidic soils when used in conjunction with cement waste bed liners, a cement matrix, and/or glass matrix materials that buffer against acidic groundwater attack. 


\section{ACKNOWLEDGMENTS}

This work supported by the U.S. Department of Energy, Office of Technology Development, under contract W-31-109-ENG-38.

\section{REFERENCES}

1. D.J. Wronkiewicz, X. Feng, N.R. Brown, and T. DiSanto, in Emerging Technologies in Hazardous Waste Management VI, edited by D.W. Tedder (The Am. Chem. Soc., Atlanta, GA, 1984) pp. 645-648.

2. D.J. Wronkiewicz, S.F. Wolf, E.C. Buck, T. DiSanto, M.T. Surchik, J.A. Fortner, N.L. Dietz, J.W. Richardson, J.S. Luo, X. Feng, M. Gong, and N.L Brown, Argonne National Laboratory, unpublished information (1995).

3. N.R. Selberg, A.G. Chambers, W.K. O'Connor, G.L. Anderson, and T.L. Eddy, in Proc. Inter. Symp. Environ. Tech., Plasma Systems and Applications, Vol. 1, Oct. 8-11, Atlanta, GA, p. 227(1995).

4. $\quad$ W.L. Ebert, J.K. Bates, and W.L. Borcier, Waste Mgmt. 11, 205 (1991).

5. D.J. Wronkiewicz, C.R. Bradley, J.K. Bates, and L.M. Wang, in Scientific Basis for Nuclear Waste Management XVII, edited by A. Barkatt and R.A. Van Konynenburg (Mat. Res. Soc. Symp. Proc. 333, Pittsburgh, PA, 1994) pp. 259-267.

6. H. Hidaka, K. Takahashi, and P. Holliger, Radiochim. Acta 66/67, 463 (1994).

7. D.J. Wronkiewicz, C.R. Bradley, and J.K. Bates, Geological Society of America, Abstracts with Program, p. A-185 (1993).

8. W.L.Ebert, The Effects of the Glass Surface Area/Solution Volume Ratio on Glass Corrosion: A Critical Review, Argonne National Laboratory Report ANL-94/34, Argonne IL (1995).

9. C.M. Jantzen, N.E. Bibler, D.C. Beam, C.L. Crawford, and M.A. Pickett, Characterization of the Defense Waste Processing Facility (DWPF) Environmental Assessment (EA) Glass Standard Reference Material, Westinghouse Savannah River Company Report WSRC-TR-92-346 (1993).

10. T.J. White, G.F. Eaton, J. Kyle, and F. Lincoln, in Extraction and Processing for the Treatment and Minimization of Wastes, edited by J. Hager, B. Hansen, W. Imrie, J. Pusatori, and V. Ramachandran (The Min., Metals, and Mat. Soc., Warrendale, PA, 1993) pp. 217-227.

11. M. Kaneko, Y. Shoji, H. Matsuura, and N. Yanasaki, in Scientific Basis for Nuclear Waste Management XVIII, edited by T. Murakami and R.C. Ewing (Mat. Res. Soc. Symp. Proc. 353, Pittsburgh, PA, 1995) pp. 791-798.

\section{DISCLAIMER}

\footnotetext{
This report was prepared as an account of work sponsored by an agency of the United States Government. Neither the United States Government nor any agency thereof, nor any of their bility for the accuracy, completeness, or implied, or assumes any legal liability or responsiprocess disclosed, or represents that its use woulness of any information, apparatus, product, or ence herein to any specific commercial use would not infringe privately owned rights. Refermanufacturer, or otherwise does not product, process, or service by trade name, trademark, mendation, or favoring by the United States and opinions of authors expressed herein Government or any agency thereof. The views United States Government or any agency thereof. necessarily state or reflect those of the
} 